\title{
Autologous AML/Dendritic Cell Fusion Vaccine
}

National Cancer Institute

\section{Source}

National Cancer Institute. Autologous AML/Dendritic Cell Fusion Vaccine. NCI Thesaurus.

Code C148214.

A therapeutic cell-based cancer vaccine consisting of autologous dendritic cells (DCs) fused with autologous acute myeloid leukemia (AML) cells, with potential immunostimulatory and antineoplastic activities. The autologous AML/DC fusion vaccine is generated in vitro by mixing DCs and irradiated AML cells harvested from individual patients, in the presence of polyethylene glycol (PEG), to produce hybrid DC-leukemia fusion cells. Upon re-administration, the autologous AML/DC fusion vaccine may elicit a cytotoxic T-lymphocyte (CTL)-mediated antitumor immune response ag ainst a broad array of AML-associated antigens, which may lead to AML cell lysis. 